\title{
Effect of Predigested Artificial Diet Using Papain Enzyme on the Degree of Protein Hydrolysis and Protease Enzyme Activity of Mud Crab (Scylla olivacea) Larvae at Zoea 2 and 3 Stages
}

\author{
Haryati*), Yushinta Fujaya, and Edison Saade \\ Faculty of Maritime and Fisheries Science of Hasanuddin University, Indonesia \\ ${ }^{*}$ Corresponding author: haryati_fikpunhas@yahoo.com
}

Received: 20 March 2018; Accepted: 27 August 2018

\begin{abstract}
Haryati, Yushinta Fujaya, and Edison Saade. 2018. Effect of Predigested Artificial Diet Using Papain Enzyme on the Degree of Protein Hydrolysis and Protease Enzyme Activity of Mud Crab (Scylla olivacea) Larvae at Zoea 2 and 3 Stages. Aquacultura Indonesiana, 19 (2): 76-82. The ability of mud crab (Scylla olivacea) larvae to digest artificial diet depends on the availability of digestive enzyme. To enhance the larvaes capability to utilize artificial diet can be conducted by adding exogenous enzyme to the diet.The aim of this research was to determine the dose of papain enzyme and stadia of predigest artificial diet that produced the best degree of protein hydrolysis and protease enzyme activity. Completely randomized designwas used to evaluate the effect of papain enzyme dose on the degree of protein, with four treatment and three replications, namely the doses of $0.0 \%, 1.5 \%, 3.0 \%$, and $4.5 \%$. Factorial pattern with the completely randomized design was used to evaluate the effect of papain enzyme dose and the proper predigest artificial feeding stage on the activity of protease enzyme. The first factor was the papain enzyme dose $(0.0 \%, 1.5 \%, 3.0 \%$, and $4.5 \%)$, while second factor was the stadia of larvae when it is fed with predigested artificial diet (zoea 2 and zoea 3 stadia). The research showed that the difference of papain enzyme dose provides real effect on degree of protein hydrolysis either on JP 0 or JP 1 diet brands $(\mathrm{P}<0.05)$. Degree of protein hydrolysis of the diet predigested with $0.0 \%$ papain enzyme was the lowest and has real difference $(\mathrm{P}<0.05)$ with the $1.5 \%, 3.0 \%$ and $4.5 \%$ doses. Degree of protein hydrolysis on $3 \%$ dose of papain enzyme does not provide real difference with the $4.5 \%$, namely $19.753 \%$ and $22.890 \%$ respectively in JP $0,18.707 \%$ and $20.430 \%$ in JP 1 , but has real difference $(\mathrm{P}<0.05)$ with $1.5 \%$ doses. The difference papain enzyme dose and stadia of predigest artificial diet as well as the interaction between both of them had significant effect $(\mathrm{p}<0.05)$ on the activity of protease enzyme. On the larvae of zoea 2 stadia, the activity of protease enzyme on the larvae fed with predigest artificial diet starting from zoea 2 stadia with $3.0 \%$ and $4.5 \%$ papain enzyme dose or those still fed with natural diet does not provide real difference, but is higher and provides real difference than $0 \%$ and $1.5 \%$ doses. On the larvae of zoea 3 stadia, the activity of protease enzyme to the larvae fed with artificial diet starting from zoea 2 with $0 \%$ and $1.5 \%$ papain enzyme doses, and those fed with artificial diet starting from zoea 3 stadia with $0 \%$ papain enzyme dose does not provide real difference ( $p>0.05$ ) but is lower and provides real difference than other treatments. Protease enzyme activity on the larvae fed with predigest artificial diet using $4.5 \%$ papain enzyme starting at zoea 2 stadia, was not significantly different $(\mathrm{P}<0.05)$ compared to larvae fed artificial diet which was predigest with $0.0 \%, 1.5 \%$, 3.0 and 4.5 papain enzyme started at Zoea 3. Based on the degree of protein hydrolysis, papain enzymes can be used to hydrolyze artificial diet in doses ranging from $3.0 \%$ to $4.5 \%$. Based on the activity of protease enzymes, mud crab larvae (Scylla olivacea) predigested artificial diet using $4.5 \%$ papain enzyme can be provided to the larvae starting from zoea 2 stadia.
\end{abstract}

Keywords: Degree of protein hydrolysis; Larva stadia, Protease enzyme activity; Papain enzyme dose; Scylla olivacea

\section{Introduction}

Mud crab (Scylla olivacea) is an essential economic fisheries commodity. Seed availability is one of defining factors in aquaculture activities. Until now, the seeds in mud crab aquaculture are still obtained from fishing in nature which is fluctuating and its availability becomes a restricting factor. The use of natural seed for aquaculture can also lower population and the aquaculture activity is also included as a non-environmentally friendly aquaculture category. According to Regulation of Maritime and Fisheries Ministry of Republic of Indonesia Number 1/PERMEN-KP/2015, Scylla can be captured if its carapace width is over 15 $\mathrm{cm}$. This regulation is revoked since the existence and availability of mud crab in nature has dropped. To address the issue, the development of seed provision through hatchery process is really important for sustainable mud crab breeding.

One of defining factors for the success of hatchery process is diet. The diet usually used is 
natural diet. In a big-scale hatchery process, the time of natural diet use has to be restricted and its role is replaced by artificial diet. However, the use of artificial diet is also restricted since as long as digestive organs are not ready yet and digestive enzyme has yet to be secreted, fish larvae cannot digest diet properly. The research of Haryati et al. (2014) showed that the greatest relative change on the activity of tripsin, lipase, and $\alpha$ amilase enzyme occurs earliest on Scylla larvae (Scylla olivacea) from zoea 2 to zoea 3 stadia. According to the study of the development of those enzymes, artificial diet may be provided starting from zoea 3 stadia. After that, Haryati et al. (2015) researched the effect of the replacement of natural diet with artificial diet which the used diet was commercial diet. The research showed that on the treatment of Scylla larvae starting from zoea 1 to megalopa stadia, new artificial diet can be provided starting from zoea 3 stadia. The optimization of the use of artificial diet in treating larvae to be implemented more quickly can be conducted by pre-digesting the diet which will be used, by adding exogenous enzyme to the diet. One of exogenous enzymes which can be used is papain enzyme. According to Suhartono (2005) and Muchtadi et al. (1992), papain enzyme is used to break or decompose peptide bond from protein into simpler molecules. The research about the enhanced use of diet protein using papain enzyme has been conducted by several researchers. The research of Hasan (2000) on carp showed that the addition of 1.3 to $1.7 \%$ papain enzymes to artificial diet can promote growth rate. According to Amalia et al. (2013), the best dose of papain enzyme on dumbo cat fish seed (C. gariepinus) was $2.25 \%$. Research of Hamzah (2015) on star pomfret larvae (Trachinotus blochhii) showed that the artificial diet predigested using papain enzyme with $4 \%$ dose can be given to the larvae from the age of 12 days, while the research of Putri (2015) showed that artificial diet without being predigested can be given to star pomfret after it reaches 18 days old. Research of Hutabarat et al. (2015) on freshwater crayfish seed showed that diet utilization efficiency (EPP), protein efficiency ratio (PER) and relative growth rate (RGR) after adding papain enzyme with $3.375 \%$ dose provides better response than 1.125 and $2.25 \%$ doses but provides similar response on survival rate. The aim of this research was to determine the dose of papain enzyme and stadia of predigest artificial diet that produced the best degree of protein hydrolysis and protease enzyme activity.

\section{Materials and Methods}

\section{Time and Place of the Study}

This study was conducted at Takalar Brackish Water Aquaculture Center from July to August, 2017. Analysis on the degree of protein hydrolysis was conducted at Animal Feed Chemicals Laboratory of Animal Husbandry Faculty, Hasanuddin University. Analysis of protease enzyme activity was conducted at Nutrition and Feed Technology Laboratory of Fishery and Marine Science Faculty, Hasanuddin University

\section{Source of Larvae}

Mud crab (Scylla olivacea) larvae used in this research was obtained from egg hatching. The mud crab broodstock was fed with squid and trash fish of $15 \%$ biomass per day with twice feeding a day at $06.00 \mathrm{am}$ and $06.00 \mathrm{pm}$.

\section{Papain Enzyme}

The papain enzyme used in this research was Newzime brand produced by Jepara Brackish Aquaculture Center (BBAP). Preparing and adding papain enzyme to the diet was as follows: first, papain enzyme powder (based on treatment dose) was dissolved in $10 \mathrm{~m}$ aquadest. The solution was then vortexed and left for $10-$ 15 minutes. The enzyme was then mixed with artificial diet and incubated for 60 minutes (Hasan, 2000). The incubated diet was ready to be fed to the larvae.

\section{Feed of the Larvae}

Natural diet used was Brachionus sp. on the larvae fed with artificial diet starting from zoea 2 stadia, combination of natural diet and artificial diet starting from zoea 1 to 2 stadia, density of Brachionus of 15 individual $/ \mathrm{mL}$ and artificial diet of $2.5 \mathrm{mg} / \mathrm{L}$. On the larvae fed with artificial diet starting from zoea 3 stadia, Brachionus sp.was provided from zoea 1 to 2 stadia, density of Brachionus of 30 individual $/ \mathrm{mL}$, combination of Brachionus and artificial diet is provided from zoea 2 to 3 stadia. Artificial diet used was commercial artificial diet in form of powder of Jp 0 and $\mathrm{Jp} 1$ brands. Jp 0 was provided during adaptation from zoea 1 stadia while Jp1 was provided in zoea 3 stadia. Scylla larvae of zoea 1 to 3 stadia were fed with artificial diet for $5.0 \mathrm{mg} / \mathrm{L} / \mathrm{day}$ while of zoea 3 to 
megalopa stadia was fed with artificial diet for 10 $\mathrm{mg} / \mathrm{L}$. Artificial diet was provided six times a day at $6 \mathrm{am}, 9 \mathrm{am}, 12 \mathrm{am}, 3 \mathrm{pm}, 6 \mathrm{pm}$, and $9 \mathrm{pm}$. The composition of diet nutrition was provided on Table 1.

Table 1 . Result of proximate analysis (\% of dry matter) of artificial diet in use.

\begin{tabular}{lcc}
\hline Composition & JP 0 & JP 1 \\
& Diet & Diet \\
Protein & 45.69 & 44.53 \\
Fat & 9.03 & 9.37 \\
Crude fiber & 2.13 & 1.65 \\
NFE & 29.16 & 29.65 \\
Ash & 13.99 & 14.80 \\
\hline
\end{tabular}

\section{Experimental Design}

To evaluate the effect of papain enzyme dose on the degree of protein hydrolysis, completely randomized design with four treatments was used, namely $0.0 \%, 1.5 \%, 3 \%$, and $4.5 \%$ papain enzyme doses with three replication. To evaluate the effect of papain enzyme dose and the stadia of predigested artificial diet provision using papain enzyme, factorial pattern with complete random basic design was used. The first factor was enzyme papain doses of $0 \%, 1.5 \%, 3.0 \%$, and $4.5 \%$ and the second factor was the stadia of predigest artificial diet provision from zoea 2 and zoea 3 stadia.

\section{Parameters}

\section{Degree of Protein Hydrolysis}

Analysis of degree of protein hydrolysis was conducted in-vitro. Ten grams of diet to be predigested was scaled, papain enzyme was added to the diet based on the experimented treatment $(0.0 \%, 1.5 \%, 3.0 \%$, and $4.5 \%)$ which has previously has been dissolved with $1 \mathrm{~mL}$ aquadest. The mixture was then incubated for 60 minutes.

After completing incubation, $0.5 \mathrm{~g}$ of diet sample was taken and protein hydrolysis reaction was halted by adding $1.5 \mathrm{~mL}$ of $7 \%$ trichloroacetate solution and left in room temperature. After that, $3.0 \mathrm{~mL}$ Tris $\mathrm{HCl}$ buffer (pH 6.5) was added and centrifuged with 10,000 rpm speed for 20 minutes. The produced deposit was used to analyze total protein level using Kjeldahl method. Diet's degree of protein hydrolysis was calculated using the following formula:
Where:

$$
\mathrm{DHP}=\frac{\mathrm{Po}-\mathrm{Pt}}{\mathrm{Po}} \times 100
$$

DHP = degree of protein hydrolysis

Po = diet protein level before hydrolysis

$\mathrm{Pt}=$ diet protein level after hydrolysis in $\mathrm{t}$ time frame

\section{Protease Enzyme Activity}

Larva sampling for protease enzyme activity analysis was conducted on zoea 2 and zoea 3 stadia. Before that, larva was fed with diet for 1 hour based on the experimented treatments. Protease enzyme activity ((U/mg larva/minute)) was estimated with Bergmeyer and Grassi (1974) method. To measure the enzyme activity, casein substrate and phosphate buffer are used (pH 7.6). Tyrosine was used as a standard, which 1 enzyme unit was equivalent with $1 \mathrm{mg}$ tyrosine release for 1 minute. Protease enzyme activity was calculated using the following formula Bergmeyer and Grassi (1974).

$$
\text { Protease activity } \quad=\frac{\text { Act }-\mathrm{Abl}}{\text { Ast }-\mathrm{Abl}} \times \mathrm{P}^{\mathrm{N}} \mathrm{T}^{-1}
$$

Where:

$$
\begin{aligned}
& \text { Act }=\text { sample absorbance value } \\
& \text { Abl }=\text { blank absorbance value } \\
& \text { Ast }=\text { standard absorbance value } \\
& \mathrm{P}=\text { dissolving factor } \\
& \mathrm{T}=\text { incubation time (minute) }
\end{aligned}
$$

\section{Statistical Analysis}

One-way ANOVA was used to evaluate the effect of papain enzyme dose on the degreee of protein hydrolysis, and the effect of papain enzyme dose and difference of predigest artificial feeding stadia on the protease enzyme activity. Significant differences between treatment means were identified bu the W-Tukey test. Differences were deemed statistically significant at $\mathrm{P}<0.05$.

\section{Result and Discussion}

\section{Degree of Protein Hydrolysis}

Degree of protein hydrolysis on diet with various papain enzyme doses is provided on Table 2. Result of various analyses showed that different papain enzyme doses provide real effect $(\mathrm{p}<0.05)$ on degree of protein hydrolysis either on JP 0 or JP 1 diets. W-Tukey test showed that degree of protein hydrolysis either on JP 0 or JP1 on $3.0 \%$ and $4.5 \%$ papain enzyme doses, does not provide real difference $(\mathrm{p}>0.05)$ but was higher, 
$19.753 \%$ and $22.890 \%$ respectively in JP 0 , $18.707 \%$ and $20.430 \%$ in JP 1 , and provides real difference $(\mathrm{p}<0.05)$ than $0.0 \%$ and $1.5 \%$ doses. Degree of protein hydrolysis on JP 0 diet with $0 \%$ papain enzyme dose was lower and provides real difference $(\mathrm{p}<0.05)$ than $1.5 \%$ dose while JP 1 does not provide real difference $(p>0.05)$. Protein hydrolysis is the process of breaking covalent bonds connecting protein-creating amino acids. In hydrolysis process, covalent bonds among amino acid molecules will be broken to produce free amino acid. Degree of protein hydrolysis is affected by several factors namely enzyme concentration, hydrolysis time, and used enzyme. Low degree of protein hydrolysis on $0.0 \%$ and $1.5 \%$ enzyme doses occurs since enzyme concentration is not sufficient to hydrolyze substrate. Research of Kurniawan (2012) showed that the lowest degree of protein hydrolysis of squid ink on $0.0 \%$ papain enzyme dose is $1.69 \%$ and the highest degree of hydrolysis value on $2.0 \%$ dose is $34.51 \%$. Research of Haslaniza et al. (2010) showed that substrate concentration difference causes difference on the produced degree of hydrolysis.

\section{Enzyme Activity}

Result of variance analyses of protease enzyme activity on larvae in zoea 2 and 3 stadia showed that difference papain enzyme dose and different stadia of predigest artificial feedingas well as interaction between both of them had significant effect $(p<0.05)$. Protease enzyme activity of mud crab larvae on zoea 2 and 3 stadia respectively were provided on Table 3 and 4 while interaction between enzyme dose and larvae stadia were provided on Figure 1 and 2.

Table 2. Degree of protein hydrolysis (\%) of diet with various papain enzyme doses

\begin{tabular}{ccc}
\hline \multirow{2}{*}{ Enzyme Dose $(\%)$} & \multicolumn{2}{c}{ Degree of protein hydrolisis (\%) } \\
\cline { 2 - 3 } & JP O Diet & JP 1 Diet \\
\hline 0.0 & $2.863^{\mathrm{a}} \pm 0.2951$ & $2.667^{\mathrm{a}} \pm 0.0499$ \\
1.5 & $6.390^{\mathrm{b}} \pm 1.7935$ & $3.903^{\mathrm{a}} \pm 0.3555$ \\
3.0 & $19.753^{\mathrm{c}} \pm 0.2288$ & $18.707^{\mathrm{b}} \pm 0.4974$ \\
4.5 & $22.890^{\mathrm{c}} \pm 0.7414$ & $20.430^{\mathrm{b}} \pm 1.0995$ \\
\hline
\end{tabular}

Note: Similar letters on similar column shows no real difference result on $5 \%$ rate.

Table 3. Average protease enzyme activity on mud crab larvae (Scylla olivacea) of zoea 2 stadia fed with predigested artificial diet using papain enzyme and different stadia of artificial feeding.

\begin{tabular}{cc}
\hline Treatment & Enzyme activity (U enzyme/ g larvae/minute) \\
\hline P0.0Z2 & $0.0581 \pm 0.0031^{\mathrm{a}}$ \\
P1.5Z2 & $0.1872 \pm 0.0045^{\mathrm{b}}$ \\
P3.0Z2 & $0.3058 \pm 0.0228^{\mathrm{c}}$ \\
P4.5Z2 & $0.3692 \pm 0.0186^{\mathrm{d}}$ \\
P0.0Z3 & $0.3703 \pm 0.0061^{\mathrm{d}}$ \\
P1.5Z3 & $0.3695 \pm 0.0053^{\mathrm{d}}$ \\
P3.0Z3 & $0.3711 \pm 0.0055^{\mathrm{d}}$ \\
P4.5Z3 & $0.3715 \pm 0.0035^{\mathrm{d}}$ \\
\hline
\end{tabular}

Note: Different letters on the same column shows real different result ( $p>0.01$ ); P (papain enzyme dose); $\mathrm{Z}$ (zoea 2 and 3 larvae stadia)

Table 4. Average protease enzyme activity on mud crab larvae (Scylla olivacea) of zoea 3 stadia fed with predigested artificial diet using papain enzyme and different stadia of artificial feeding.

\begin{tabular}{cc}
\hline Treatment & Enzyme activity (U enzyme/g larvae/minute) \\
\hline P0.0Z2 $1.5 Z 2$ & $0.2542 \pm 0.0123^{\mathrm{a}}$ \\
P3.0Z2 & $0,2901 \pm 0.0029^{\mathrm{a}}$ \\
P4.5Z2 & $0.4509 \pm 0.0059^{\mathrm{cd}}$ \\
P0.0Z3 & $0.5402 \pm 0.0161^{\mathrm{de}}$ \\
P1,5Z3 & $0.3105 \pm 0.0152^{\mathrm{ab}}$ \\
P3.0Z3 & $0.3949 \pm 0.0295^{\mathrm{bc}}$ \\
P4.5Z3 & $0.5899 \pm 0.0133^{\mathrm{e}}$ \\
\hline
\end{tabular}

Note: Similar letters on the same column shows no real difference result ( $<<0.05)$; P (papain enzyme dose); Z (zoea 2 and 3 larvae stadia) 


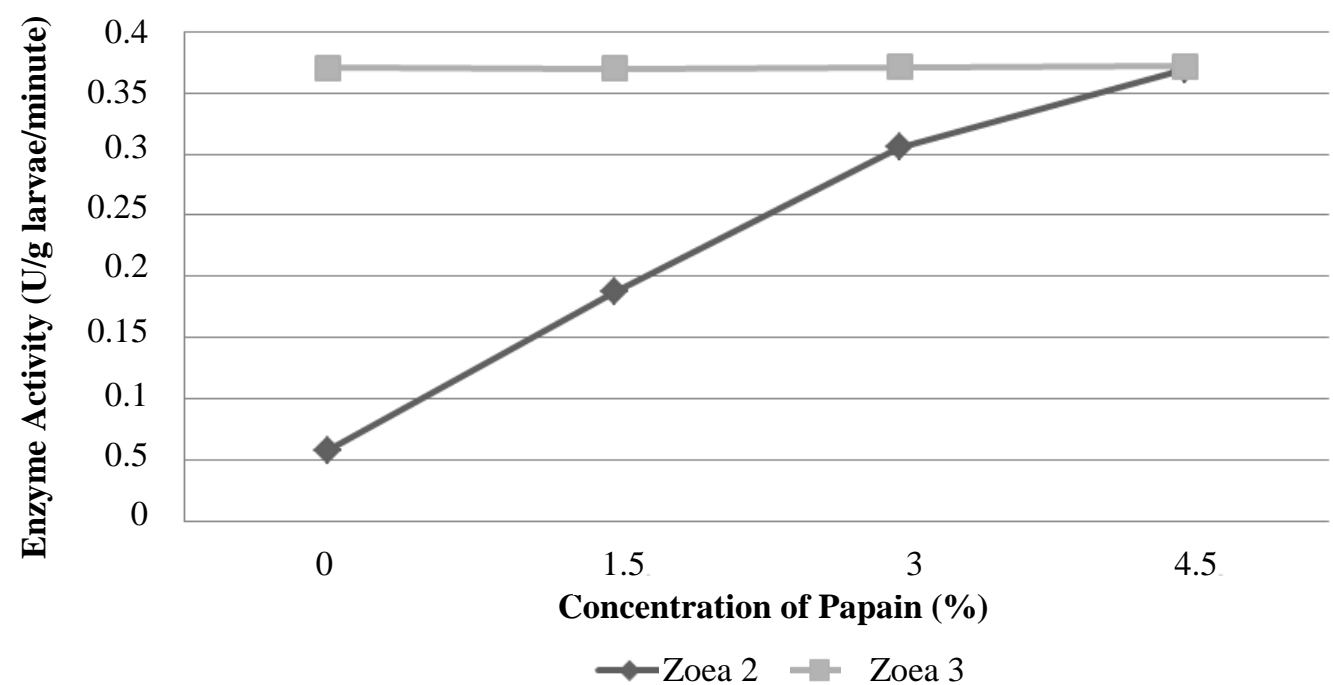

Figure 1. Interaction between papain enzyme dose and the stadia of larvae fed with predigest artificial diet on protease enzyme activity of larvae in zoea 2 stadia

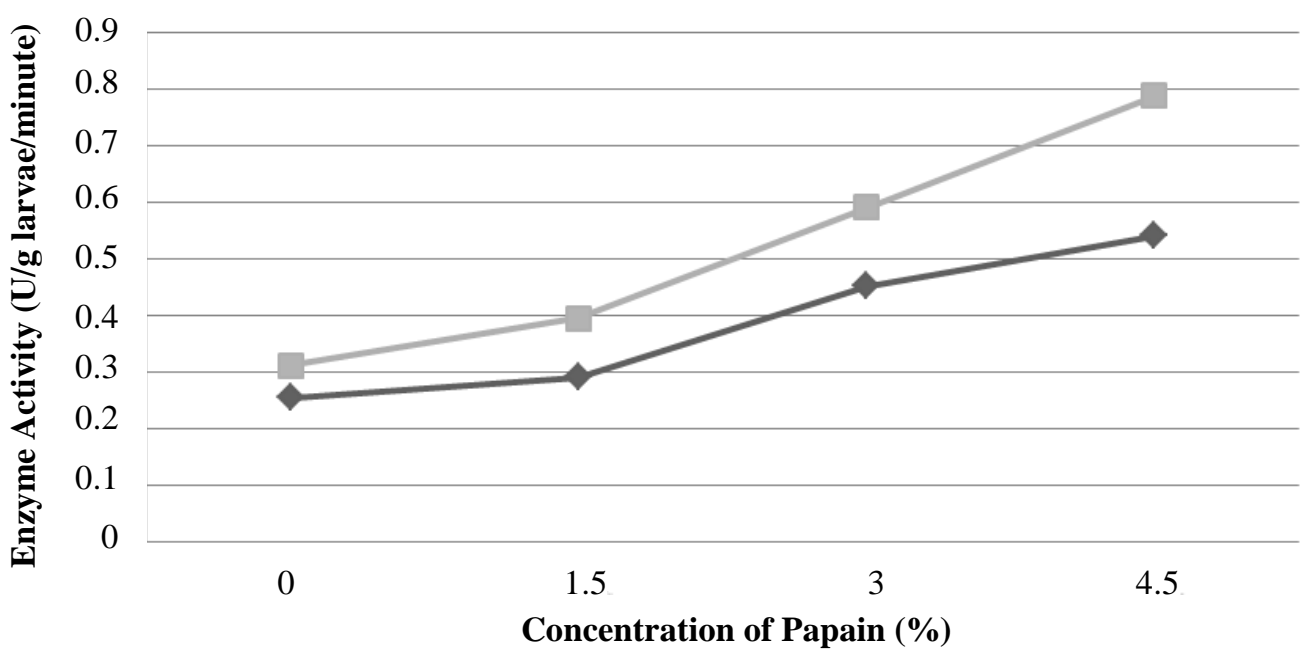

\section{$\multimap$ Zoea $2-$ Zoea 3}

Figure 2. Interaction between papain enzyme dose and stadia of larvae fed with predigest artificial diet on protease enzyme activity of larvae in zoea 3 stadia

Result of W-Tukey test showed that protease enzyme activity on zoea 2 stadia to the larvae fed with artificial diet from zoea 2 stadia with $0 \%$ papain enzyme dose $(0.2542 \mathrm{U}$ enzim/g larvae/minute) was the lowest and provides real difference $(p<0.05)$ than other treatments. It occurs since on the stadia, enzyme has yet to be produced, so larvae are not able to hydrolyze protein properly. Research of Haryati et al. (2014) showed that protease, lipase, or $\alpha$-amilase enzymes on Scylla larvae (Scylla olivacea) are produced on zoea 3 stadia and on that stadia, artificial diet may be given. The result of this research is also suitable with the research of Jantrarotai et al. (2005) showed that the digestive organs of Scylla olivacea larvae are histologically complete on zoea 3 stadia. With complete digestive organs, digestive enzymes start to be produced. Moreover, research of Haryati et al (2015) showed that the activity of protease, lipase, or $\alpha$ - amilase enzymes on mud crab larvae (Scylla olivacea) fed with artificial diet on zoea 2 stadia was also low. The survival rate of larvae fed with artificial diet on the stadia is also the lowest $(7.7 \%)$ than those fed with artificial diet on zoea $3(37.80 \%)$ and zoea 4 stadia $(47.10 \%)$.

Enzyme activity on the larvae fed with predigest diet on zoea 2 stadia with $1.5 \%$ or $3.0 \%$ papain enzyme doses was also lower and provides real difference result $(\mathrm{P}<0.05)$ than those fed with diet pre-digested using $4.5 \%$ papain enzyme or with natural diet, which was larvae which will be fed with artificial diet on 
zoea 3 stadia. Enzyme activity on $4.5 \%$ papain enzyme dose does not provide real difference $(\mathrm{p}<0.05)$ than those fed with natural diet. It showed that the addition of papain enzyme on the dose can optimally enhance enzyme activity so it is similar with enzyme activity on the larvae fed with natural diet.

In zoea 2 stadia larvae showed that the increasing dose of papain enzyme, protease enzyme activity also increased. On the larvae fed with natural diet, enzyme activity was higher than those fed with artificial diet on zoea 2 stadia. On $4.5 \%$ papain enzyme dose, protease enzyme activity was relatively similar with those fed with natural diet (Figure 1).

Result of W-Tukey test showed that protease enzyme activity on Scylla larvae on zoea 3 stadia fed with artificial diet starting from zoea 2 stadia with $0.0 \%$ and $1.5 \%$ papain enzyme doses and those fed with artificial diet from zoea 3 stadia with $0.0 \%$ papain enzyme dose does not provide real difference $(p>0.05)$ but was lower and provides real difference $(\mathrm{P}<0.05)$ than other treatments. Enzyme activity on larvae fed with artificial diet with $4.5 \%$ papain enzyme dose from zoea 2 stadia also does not provide real difference than those fed with artificial diet from zoea 3 stadia with 3.0\% papain enzyme dose.

Protease enzyme activity on star pomfret larvae (Trachinotus blochii) fed with artificial diet predigested using $4 \%$ papain enzyme dose on the ages of 12 and 15 days does not provide real difference, but was higher and provides real difference than those fed with artificial diet not predigested or predigested using $1 \%, 2 \%$ and $3 \%$ papain enzyme doses (Haryati et al., 2016). According to the research, star pomfret larvae can be fed with artificial diet predigested using $4 \%$ papain enzyme dose on the age of 12 days. Research of Putri (2015) showed that without being predigested, artificial diet can only be given when larvae reach 18 days old. The research showed that artificial diet predigested using $4 \%$ papain enzyme can be given earlier.

Lower enzyme activity occurs since enzyme dose added to the diet has not been able to properly hydrolyze diet. Enzyme activities are affected by enzyme concentrate and substrate concentrate. Increased enzyme concentration will increase enzyme activity proportionally.

Enzyme concentration increase will proportionally increase enzyme activity. It is supported by the opinion from Sorgelloos et al. (1998) that exogenous enzyme in diet will hydrolyze diets nutrition in form of macromolecule into simpler molecules so larvae can digest the diet properly. According to the result of this research, in rearing mud crab (Scylla olivacea) larvae, artificial diet predigested using $4.5 \%$ papain enzyme can be given starting from zoea 2 stadia.

This research can be concluded that $3.0 \%$ and $4.5 \%$ papain enzyme doses provide similar responses on degree of protein hydrolysis and was higher than $0.0 \%$ and $1.5 \%$ doses. Protease enzyme activity on Scylla larvae in zoea 2 stadia fed with artificial diet predigested using $4.5 \%$ papain enzyme was equivalent with those fed with natural diet, but was higher than those fed with artificial diet predigested using $0.0 \%, 1.5 \%$, and $3.0 \%$ papain enzymes. In rearing mud crab larvae (Scylla olivacea), artificial diet predigested using $4.5 \%$ papain enzyme can be given to the larvae from the zoea 2 stadia.

\section{Acknowledgement}

Thanks to the Ministry of Research Technology and Higher Education who has funded this research, through the PUPT research fund in 2017. Thanks also to the Center for Brackish Water Aquaculture Takalar South Sulawesi in which this research has been conducted.

\section{References}

Amalia, R., Subandiyono, and A. Endang. 2013. The effect of using papain onfeed protein utilization rate and growth of dumbo catfish (Clarias gariepinus). Journal of Aquaculture Management and Technology, 2(1): 136 - 143 .

Bergmeyer, H.U. and M. Grassi. 1974. Methods of Enzymatic Analysis, Vol. 2. Academic Press, $682 \mathrm{pp}$.

Hamzah, H. 2015. The effectiveness of adding papain enzyme to artificial feed on the survival and growth of larval fish larvae Trochinotus blochii Lacepede, 1801. Thesis. Graduate Program, Hassanudin University, $53 \mathrm{p}$.

Haslaniza, H., M.Y. Maskat, W.M. Wan Aida, and S. Mamot. 2010. The effect of enzyme concentration, temperature and incubation time on Nitrogen content and degree of hydrolysis of protein precipitate from cockle (Anadara granosa) meat wash water. International Food Research Journal, 17: 147 - 152 .

Haryati, Y. Fujaya, E. Saade, Zainuddin, and Aslamiah. 2014. The development of the of digestive enzymes activity of larval mud crab ( Scylla olivacea ) zoea to megalopa stages and its relationship with the ability to 
use artificial feed. Jurnal Aquacultura Indonesiana, Vol. 15 (1): 35 - 41.

Haryati, Y. Fujaya, and Anugrah. 2015. The effect of the replacement of live foods with artificial diets on the digestive enzyme activity of mud crab ( Scylla olivacea) larvae. Proceding of National Seminar of fisheries and marine sciences XII, Gajahmada University, pp. $137-144$.

Haryati, H. Hamzah, and E. Saade. 2016. Effect of using papain enzyme in artificial diet on the degree of protein hydrolysis and protease enzyme activity of silver pompano larvae (Trachinotus bloochii, Lacepede 1801). Proseding $3^{\text {th }}$ National Symposium of Marine Sciences and Fisheries, Hasanuddin University, pp. $367-373$

Hasan, O.D.S. 2000. The effect of using papain enzyme in artificial feed on protein utilization and growth of gouramy seed (Ospronemus gouramy Lac.). Thesis. Bogor Agricultural University, $57 \mathrm{p}$.

Hutabarat, G.M., D. Rachmawati, and Pinandoyo. 2015. Performance of freshwater lobster growth (Cherax quadraicarinatus) through the addition of papain enzymes in artificial feeds. Journal of Aquaculture Management and Technology,4 (1): $10-18$.

Jantrarotai, P., N. Srakae, and A. Sawanyatiputi. 2005. Histological study on the development of digestive system in zoeal stages of mud crab (Scylla olivacea). Ksetsart (Nat,Sci.,), 39: $666-671$.

Kurniawan, S. Lestari, and R.J.S. Hanggita. 2012. Hydrolysis of squid ink proteins(Loligo sp.) with papain enzyme. Fishtech,1(1): 41-54.

Minister of Marine Affairs and Fisheries of the Republic of Indonesia. 2015. Ministerial RegulationMarine and Fisheries Republic of Indonesia Number 1 / PERMEN-KP / 2015 on Lobster Catching (Panulirus spp.), Crab (Scylla spp.) and Rajungan (Portunus pelagicuss pp.)

Muchtadi, D., S.R. Palupi, and M. Astawan. 1992. Enzymes in The Food Industry. InterUniversity Center for Food and Nutrition, Bogor Agricultural University, $8 \mathrm{p}$.

Putri, D.S. 2015. Effect of replacement of natural feed with artificial feed onsurvival and growth of silver pompona larvae (Trachinotus blochii, Lacepede). Thesis. Graduate program, Hasanuddin University, $109 \mathrm{p}$.

Sorgeloos, P., P. Cotteu, P. Dhert, G. Merchie, and P. Lavens. 1998. Use of brine shirmp, Artemia sp. in larval crustacean nutrition. Review in Fisheries Science, 182: $55-68$.

Suhartono, M.T. 2005. Protease. Inter-University Center, Biotechnology,76 p. 